\title{
Neuro-ophthalmological emergencies
}

\section{Nöro-oftalmolojik aciller}

\author{
Tuba ÇELiK, Ayşe ÇEVIK
}

\section{ABSTRACT}

Neuro-ophthalmological emergencies are group of disease which may cause visual impairment or life-threatining conditions if treatment is not applied promptly. These clinical conditions can result in high rates of morbidity even with immediate therapy. Neuro-ophthalmological emergencies frequently appear with symptoms of vision loss, diplopia and anisocoria. Arterial anterior ischemic optic neuropathy is a severe condition which can be associated with permanent vision loss requiring immediate corticosteroid therapy. Cavernous sinus thrombosis and mucormycosis which can affect orbital apex and cavernous sinus are other conditions that can appear with vision loss and diplopia symptoms requiring emergency corticosteroid therapy. These diseases extend to the brain paranchymal tissue and cause permanent neurological sequelae if not treated urgently. Cerebral aneurysm causing isolated third-nerve palsy is another condition carrying risk of high morbidity. Horner Syndrome may be the initial sign of carotid dissection, which is an important cause of stroke in young adults. Immediate approach is very important in all these diseases, therefore the treatment approach should be initiated as soon as possible with the cooperation of the ophthalmologist and the neurologist.

Keywords: Neuro-ophthalmology, emergency, anterior ischemic optic neuropathy, cavernous sinus thrombosis
Öz

Nörooftalmolojik aciller, gereken tedavi yeterince uygulanmadığında görmeyi ve yaşamı tehdit edici durumlara neden olabilen bir grup hastalıktan oluşmaktadır. Erken tedavi uygulanmış olsa dahi, çoğu zaman bu klinik durumlar yüksek morbidite oranları ile sonuçlanmaktadır. Nöro-oftalmolojik aciller sıklıkla görme kaybı, çift görme ya da anizokori gibi belirtilerle ortaya çıkmaktadır. Arteriyel anterior iskemik optik nöropati kalıcı ve ciddi görme kaybı, inme veya aort disseksionu ile birliktelik gösterebilen ve acil kortikosteroid tedavisi gereksinimi duyulan ciddi bir durumdur. Görme kaybı veya çift görme belirtileriyle ortaya çıkan, kavernöz sinüsü ve orbita apeksini etkileyen kavernöz sinüs trombozu veya mukormikozis gibi hastalıklar ise erken tedavi edilmediği takdirde beyin parankim dokusuna ulaşarak kalıcı nörolojik sekellere neden olabilmektedir. Yüksek morbidite riski taşıyan bir başka durum ise serebral anevrizmaların neden olduğu izole üçüncü sinir felcidir. Horner Sendromu, genç erişkinlerde inmenin önemli nedenlerinden biri olan karotis diseksiyonunun başlangıç bulgusu olabilir. Erken müdahalenin çok önemli olduğu tüm bu hastalıklara yaklaşım, oftalmolog ve nörolog işbirliği içinde ve olabilecek en kısa sürede olmalıdır.

Anahtar kelimeler: Nöro-oftalmoloji, acil, anterior iskemik optik nöropati, kavernöz sinüs trombozu

\section{ÖYKÜ ve MUAYENE}

Acil nörolojik bir durumun değerlendirilmesinde ayrıntılı olarak alınmış öykü nöro-oftalmolojik acillerinin yönetiminde temel noktayı oluşturur. Görme kaybı, diplopi, gözde ağrı ve baş ağrısı yakınmaları, özellikle başlangıç şekli, ne kadar sürdüğü, ne sıklıkta ortaya çıktığı, beraberinde başka yakınmaların görülüp görülmediği yönünde detaylı bir şekilde sorgulanmalıdır. Daha önce geçirilmiş ya da şu anda sahip olunan diyabet gibi kronik hastalıkların ve kullanılan ilaçların sorgulanması da yarar sağlayacaktır.
Acil nöro-oftalmolojik bir duruma yaklaşımda ayrıntıIı ve sistematik bir muayene yapma gerekliliği vardır. Uzak için düzeltilmiş görme keskinliği Snellen eşeli ile yakın görme keskinliği yakın kartları ile değerlendirilmelidir. Renkli görme psödoizokromatik kartlarla muayene edilirken, her iki göz arasındaki kontrast renk duyarlılığı da kesinlikle ölçülmelidir. Görme alanı her bir göz için parmak konfrontasyonu ile dört periferik kadranda ve santral bir defekti atlamamak amacıyla Amsler Grid testi ile kontrol edilmelidir. Dokuz kardinal bakış pozisyonunda göz hareketleri muayene edilirken, alterne açma-kapama testleri ve prizma- 
lar ile deviasyon miktarı tespit edilmelidir. Pitozis, gözkapağı-kenar refle mesafesi testi ve levator fonksiyonu testleriyle ölçülmelidir. Direkt oftalmoskopi ile optik disk kenarları, rengi, çukurluğun optik diske oranı, disk ödemi, spontan venöz pulsasyon, retinal hemorajiler, arteriyel atenüasyon, venöz dilatasyon, retinal emboli değerlendirilebilir ${ }^{1,2}$.

\section{Görme Kaybı}

Görme kaybı nörooftalmolojik acil durumların temel yakınmalardan biridir. Klinik öykü ve muayene altta yatan nedenin nörolojik mi yoksa oftalmolojik mi olduğunu ayırt etmemizi sağlar. Sözgelimi, pinhol ile yapılan muayene, eğer bir refraksiyon kusuru varsa dışlanmasını sağlar. Yine Amsler Grid kartıyla yapılan muayenede santral 10 derecelik görme alanı içerisinde metamorfopsi gözlenmesi makulopati yönünde uyarıcı olur ${ }^{2}$. Sallanan fener testi ile rölatif afferent pupil defektinin (RAPD) pozitif bulunması özellikle beraberinde renkli görme sorunu da varsa optik sinir hastalığı yönünde önemli bir bulgudur ${ }^{1}$. Nörolojik bir görme kaybı tespit edildiğinde, kaybın monoküler mi binoküler mi olduğu, lezyonun optik kiyazmanın önünde ya da arkasında olduğunu belirlemek açısından değerlidir. Özellikle bilateral homonim hemianopsisi olan hastalar nazal görme alanında yaşadıkları görme kaybını temporal görme alanlarındaki iyi görmeleri ile kompanze ettikleri için görme kaybının farkında olmayabilirler².

\section{Arteritik Anterior İskemik Optik Nöropati}

İskemik optik nöropatiler ciddi görme azlığının başlıca nedenlerinden birini oluşturmaktadırlar. Optik sinirin etkilendiği kısma bağlı olarak anterior ve posterior iskemik optik nöropati olarak iki gruba ayrılır. Nonarteritik anterior iskemik optik nöropati sıklıkla hipertansiyonun eşlik ettiği en sık görülen iskemik optik nöropati grubudur. Daha az sıklıkta olan arteritik anterior iskemik optik nöropati (AAION) nörooftalmolojik bir acildir ${ }^{3}$. AAION, yaşlı hastalarda orta ve büyük arterlerin bir vasküliti olan dev hücreli arterit nedeniyle ortaya çıkmaktadır (Figür 1). Elli yaş üze- ri populasyonda insidansı 100000 kişide 0.36 olarak tahmin edilmektedir ${ }^{3}$. Dev hücreli arteritin patogenezinde olasılıkla optik sinir başında iskemi ile sonuçlanabilecek şekilde posterior silyer arter duvarında $T$ hücre aracılı granülomatöz inflamasyon yatmaktadır ${ }^{5}$. Görmeyi ve yaşamı tehdit eden bir durum olduğu için belirtilerin erken tespiti çok önemlidir. Hastaların yaklaşık \%50'sinde ani görme kaybı gelişir ve en sık gözlenen belirtidir. Diplopi ve göz ağrısı daha az sıkIıkla görülmekle beraber, hastaların \%30'unda geçici görme kaybı meydana gelir. Başlangıçta geçici görme kaybı olan hastalar da genellikle daha sonrasında kalıcı görme kaybı geliştirirler ${ }^{4,5}$. Dev hücreli arterit hastalarında görme kaybının en sık nedeni (yaklaşık \%80) AAION'dur. Santral retinal arter tıkanıklı̆̆ı, posterior iskemik optik nöropati diğer nedenler arasında görülmektedir ${ }^{4}$. Dev hücreli arterit hastaları sıklıkla baş ağrısı (\%57), çenede klaudikasyon (\%48), kilo kaybı (\%40), miyalji (\%28), anoreksia (\%31), boyun ağrısı (\%17) gibi sistemik belirtiler göstermektedir. Muayene bulgularında ise görme alanında bir ya da iki gözde defekt (\%31), tek taraflı vakalarda RAPD ve karakteristik olarak soluk optik disk ödemi, sinir lifi tabakasında infarktı gösteren retinada atılmış pamuk tarzındaki lezyonlar görülebilir. Çukurluğun optik diske oranının küçük olması, arteritik olmayan iskemik optik nöropati için önemli bir bulgu olsa da bu hastalık dev hücreli arteritle birliktelik göstermez. Temporal arterde kıvrımlanma artışı da yine tempo-

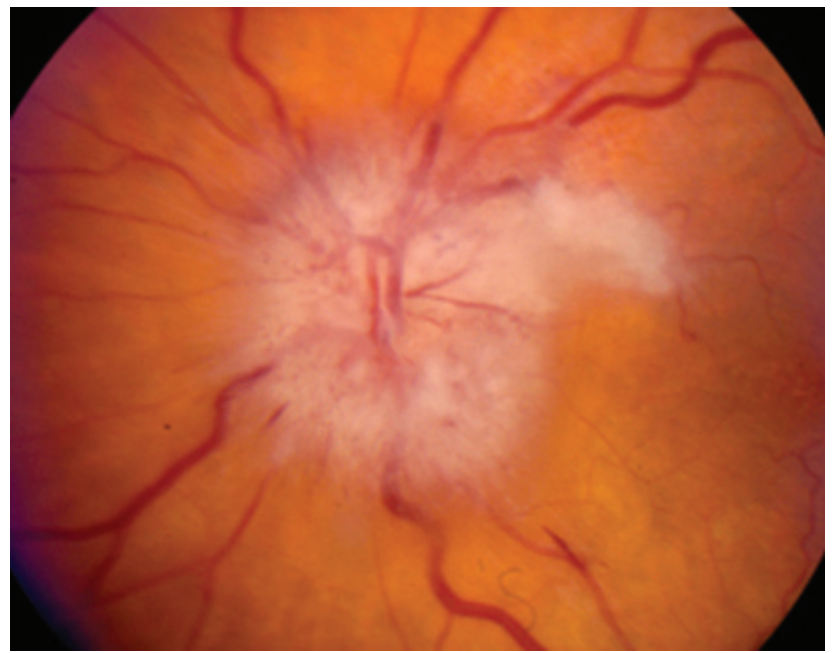

Figür 1. Dev hücreli arterit. 
ral arterit için sık görülen bir bulgudur. Bu bulguların olmaması temporal arterit tanısını dışlamaz ${ }^{5-7}$. Laboratuvar testlerinden eritrosit sedimentasyon hızında artış ve $\mathrm{C}$ reaktif protein seviyesinde artış sırasıyla $\% 85$ ve $\% 97$ duyarlılıktadır ${ }^{8}$. Diğer belirteçlerden trombositoz, lökositoz ve normositik anemi temporal arterit tanısında yardımcı olmakla birlikte, duyarlıı̆ı \%60'ın altındadır ${ }^{9}$. Temporal arter biyopsisi tanıda altın standarttır ve temporal arteritten şüphenilen tüm hastalara uygulanmalıdır. Tek taraflı temporal arter biyopsisinin negatif çıkması temporal arterit şüphelerinin çoğunu dışlamak için yeterlidir, ancak bazen güçlü kinik bulguların varlığında tek tarafıı temporal arter biyopsisi negatif olsa bile diğer taraftan temporal arter biyopsisi almak gereklidir ${ }^{10}$. Doppler ultrasonografi, pozitron emisyon sintigrafisi ve manyetik rezonans görüntüleme gibi teknikler teşhis amacıyla kullanılsa da bugüne kadar temporal arter biyopsisinin yerini alamamışlardır ${ }^{11}$. Floresein anjiografi, koroidal hipoperfüzyonu ve gecikmiş koroidal dolumu göstererek temporal arteriti arteritik olmayan iskemik optik nöropatiden ayırmak amacıyla kullanılabilir. Kortikosteroidler tedavide çok önemlidir ve görme kaybını minimal düzeyde tutabilmek amacıyla AAION tanısı konulur konulmaz acilen başlanması gerekir ${ }^{12}$. Steroid tedavisi oral ya da intravenöz olarak farklı rejimlerde uygulanabilir, ancak genellikle günde $1 \mathrm{~g}$ metilprednizolon 3 gün süreyle ve ardından günde 80-100 mg oral prednizolon şeklinde birkaç aydan birkaç yıla kadar devam edilmektedir ${ }^{13}$. Ne yazık ki hastaların çok küçük bir kısmı (\%4) steroid tedavisi altında görme keskinliğinde iyileşme kaydederken, yine hastaların \%4'ünde görme keskinliğinde kötüleşme özellikle de ilk beş günde görülür. Metotreksat, infliksimab, adalimumab gibi immünsupresif tedavilerin tek başına steroid tedavisine bir üstünlüğünün olmadığı prospektif çalışmalarda gösterilmiştir. Bu tedaviler ancak steroide bağlı komplikasyonların tehdit ettiği hastalarda kullanılabilir ${ }^{14,15}$. Aspirinin iskemik olay riskini azalttığının bilinmesi üzerine yapılan çaIışmalarda, her gün $81 \mathrm{mg}$ oral aspirin verilmesinin hastalığın ilk ortaya çıktığı anda ve takiplerde görme kaybı insidansını azalttığı gösterilmiştir ${ }^{15}$.

\section{Hipofiz Apopleksisi}

Hipofiz apopleksisi hemoraji ya da infarkt sonucu hipofiz bezinin ani bir şekide genişlemesidir (Figür 2). Apopleksi cerrahi olarak müdahale edilen adenomaların \%0,6-0,9'unda görülür. Erkeklerde (\%60) ve 5. dekattan sonra sık görülür ${ }^{16}$. Vakaların çoğunluğu spontan olsa da yaklaşık 1/3'inde hipotansiyon, malign hipertansiyon, antikoagülan ya da dopaminerjik agonistler neden olmaktadır ${ }^{17}$. Hipofiz bezinin ani genişlemesi optik kiyazma ve kavernöz sinüs gibi çevre dokular üzerinde kitle etkisi yaratmaktadır. Vakaların $\% 50$ 'sinde karakteristik olarak bitemporal görme alanında kayıp ya da sıklıkla 3. sinir paralizisi ve onu takiben gelişen 4 . ve 6 . sinir paralizilerine bağlı olarak tek ya da her iki gözde oftalmopleji meydana gelebilir. Hipofiz apopleksisi, pupilla tutulumlu, ağrılı, akut 3. sinir paralizisinin ayırıcı tanısında ender de olsa görülen bir sebeptir. Çevik ve ark. ${ }^{18}$ daha önceden hipofiz adenomu tanısı olmayan yaşlı bir hastada, pupilla tutulumunun olduğu, ağrılı izole 3 . sinir paralizisi geliştikten sonra gelişen bir hipofiz apopleksisi olgusunu sunmuşlardır. Steroid şemsiyesi altında uygulanan transsfenoidal hipofizektomi sonrası hastanın pitoz ve bakış kısıtlılığında kısmi düzelme olmuştur.

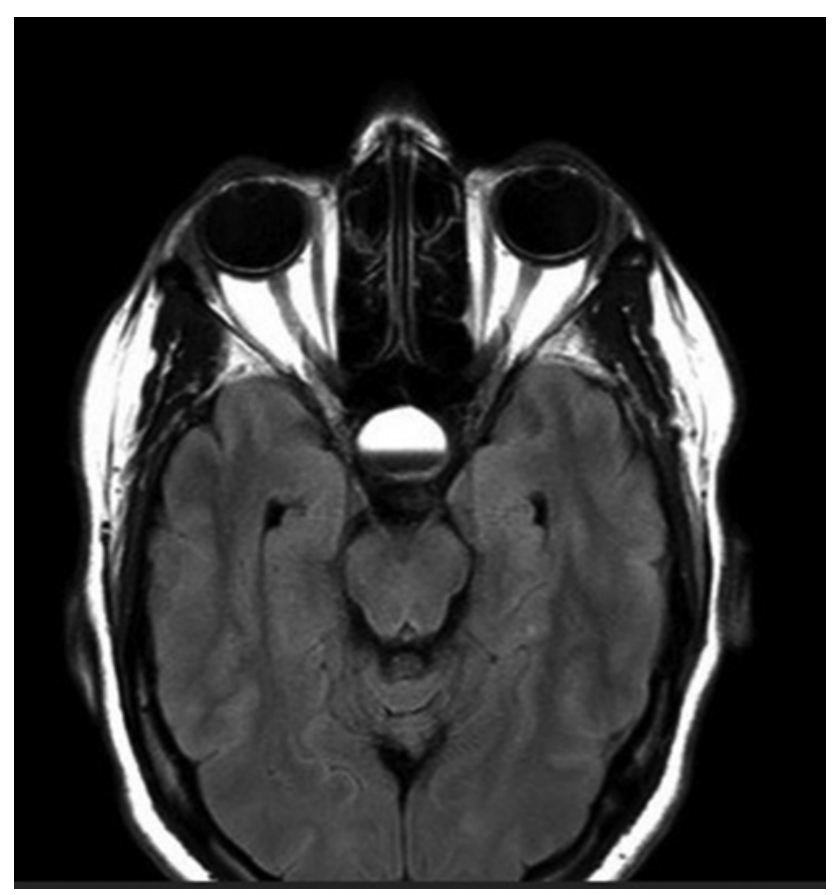

Figür 2. Hipofiz apopleksisi. 
Hipofiz apopleksisinde meningeal irritasyona bağlı başağrısı ve boyunda sertlik görülebilir. Beyin sapına ve hipotolamusa bası nedeniyle ortaya çıkan bilinç kaybı, termoregülatuvar ve kardiyovasküler disfonksiyon nedeniyle yaşamı tehdit edici bir durumdur. Ayrıca hipofiz bezinin disfonksiyonu hipotiroidizm, hiponatremi ve hiperkortizolizme neden olabilir ${ }^{19}$. Bilgisayarlı tomografi acil servislerde nörolojik görüntülemede ilk tercih olsa da duyarlılığı $\% 46^{\prime} d ı r^{20}$. Tanısal olarak manyetik rezonans görüntüleme superior bir tümörü, hemorajiyi ve ödemi göstermenin yanı sıra çevre nöral dokuları da yüksek rezolusyonla görüntüler ${ }^{19}$. Hipofiz apopleksisinin acil yönetiminde yüksek doz kortikosteroid tedavisi (6 saatte bir 100 mg hidrokortizon) sonrası transsfenoidal olarak sellanın cerrahi olarak boşaltılması yer almaktadır ${ }^{16,19}$. Özellikle ilk haftada yapılan erken dekompresyonun, vakaların \%76'sında görme keskinliğinde artışa neden olduğu ve \%79'unda görme alanında iyileşmeye neden olduğu görülmüştür ${ }^{16}$.

\section{Rino-Orbital-Serebral Mukormukozis}

Mukormukozis agresif ve şiddetli derecede yıkıcı fırsatçı bir mantar enfeksiyonudur. İmmünsuprese hastalarda özellikle de diyabet hastalarında ve nötropenisi olan hematolojik malignensilerde görülür ${ }^{21}$. Bu mantar için demir esansiyel bir büyüme faktörüdür ve desferrioksamin kullanımı mukormukozis için bir risk faktörüdür ${ }^{22}$. Bir milyonda 1.7 vaka oranında görülen ve erkeklerde kadınlara oranla 2 kat sıklıkla görüldüğü bildirilmiş bir hastalıktır23,24. Çok çeşitli formlarda görülen mukormukozis enfeksiyonu en sık rino-orbital-serebral mukormukozis (vakaların \%60'ı) olarak karşımıza çıkar ${ }^{24}$. Sporanjiyosporların inhalasyonu bulaş yoludur ${ }^{22}$. Paranazal sinüslerden yayılarak orbitayı, ağzı, damağı ve yüzü invaze edebilir. Orbital yayılım kavernöz sinüse invazyonu kolaylaştırır ve karotis arterin kavernöz segmentinin tutulumuna neden olarak intrakranial tromboza ve mikotik anevrizmaya ve bunlara bağlı olarak infarkt ve subaraknoid kanamaya neden olabilir ${ }^{25}$. Mukormukozis, optik nöropatiye bağlı erken görme kaybı geliştiren hastalarda, oftalmoplejisi, pitozisi ve kavernöz sinüs tutulumuna bağlı olarak korneal duyarlılığı azalmış hastalarda ağrılı orbital apeks sendromu olarak karşımıza çıkabilir25. Erken bulgular ateş (\%44), nazal mukozal ülserasyon (\%38), periorbital ve fasiyal ödem (\%34), görmede azalma (\%30), oftalmopleji (\%29), sinüzit (\%26), baş ağrısı (\%25), fasiyal ağrı (\%22) iken, ciltte, nazal mukozada ve damakta klasik siyah eskar vakaların ancak \%20'sinden azında görülür ${ }^{25}$. Bilgisayarlı tomografide varsa kemik erozyonu ile beraber sinüzitin varlığı ve manyetik rezonans görüntüleme ile sinüs dışına yayılım ve orbital ve serebral dokulara yayılım değerlendirilebilir, ancak görüntüleme yöntemlerinin negatif olması tanıyı hiçbir zaman dışla$\mathrm{maz}^{25}$. Mukozal lezyonlar görülmese bile klinik olarak ciddi şüphelenme durumunda paranazal sinüs biyopsisi alınabilir. Sinüs histopatolojisinin negatif olması durumunda orbital apeks biyopsisi düşünülebilir $^{25}$. Standart rino-orbital-serebral mukormukozisin tedavisi amfoterisin B (günde $5-10 \mathrm{mg} / \mathrm{kg}$ ) ile acil tedavisini içerir. Eğer olabiliyorsa enfekte olan bölge debride edilmelidir. Demir şelasyonu sağlayan dihidroksipiridinon ile idame tedavide kullanılan bir antifungal olan posakonazol ve hiperbarik oksijen tedavisi yardımcı tedavi olarak düşünülmektedir ${ }^{26}$. Uğurlu ve ark. ${ }^{27}$ dört olguluk bir seri olarak sundukları rino-orbital mukormukozisli ve başvuru sırasında görme keskinliği düzeyi ışık hissi negatif olan iki olguya ekzenterasyon uygularken, görme keskinliği 0,8 olan iki olguya sistemik amfoterisin B uygulamış ve tam iyileşme sağlandığını görmüşlerdir. Acil tedavi uygulanmazsa rino-orbital-serebral mukormukozis fataldir. Geç tanı konulması, bilateral sinüzit, immünsupresyon, hemipleji ya da hemiparezi, geniş alanlara yayılım, debridman ve antifungal tedaviye rağmen kötü prognozla sonuçlanır ${ }^{28}$.

\section{Diplopi ve Oküler Motilite Kısıtlılığı}

Çift görmesi olan hastanın değerlendirilmesi çift görme yakınmasının monoküler mi yoksa binoküler mi olduğunun tespiti ile başlar. Monoküler diplopi genellikle bir refraksiyon kusuru sonucu oluşur ve pinhol ile muayene sırasında diplopinin kaybolduğu 
görülür. Çift görmenin horizontal, vertikal, oblik ya da torsiyonel olması ve herhangi bir bakış yönünde kötüleşmesi tanı hakkında önemli ipuçları verir. Örneğin, sola bakışta artan horizontal diplopi sol 6 . sinir paralizisi ya da sağ internükleer oftalmopleji yönünden uyarıcıdır ${ }^{1,29}$.

\section{Kavernöz Sinüs Trombozu}

Kavernöz sinüs trombozu ender görülen fakat yaşamı tehdit eden bir hastalıktır. Altta yatan etiyolojiye bağlı olarak herhangi bir yaş grubunu etkileyebilir. Septik ve aseptik olmak üzere iki formu vardır. Septik kavernöz sinüs trombozu, yüzün $1 / 3$ orta bölümündeki etmoid sinüs, sfenoid sinüs, orbita, diş ve kulaktan kaynaklanan venöz sistemin enfeksiyonunun yayılması sonucu oluşur. Vakaların $2 / 3^{\prime}$ inde sorumlu patojen Stafilokokus aeurus'tur. Streptokokus pnömonia, gram negatif basiller ve anaeroblar daha az sıklıkla görülür ${ }^{30}$. Aseptik form ise sıklıkla polisitemi, vaskülit, gebelik, postpartum dönem, oral kontraseptif kullanımı gibi protrombotik olaylar neticesinde ya da travma, cerrahi ya da kafa tabanında bası ya da obstrüksiyona neden olan tümörler sonucunda meydana gelir (Figür 3).

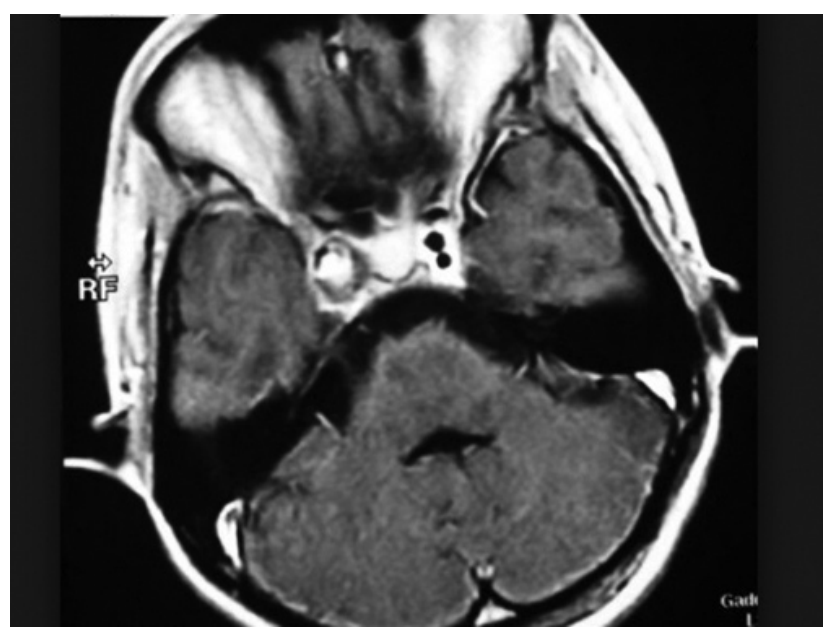

Figür 3. Kavernöz sinüs trombozu.

Kavernöz sinüs trombozunun klinik bulguları kavernöz sinüs içerisindeki yapıların direkt etkilenmesine bağlı gelişir. Septik kavernöz sinüs trombozu olan va- kaların yaklaşık \%80-100'ü ani ateş, proptozis, kemozis, pitozis ve 3,4 veya 6 . sinir paralizileri ile karşımıza çıkar. \%50-80 oranında perorbital ödem, baş ağrısı, letarji ve optik disk ödemi görülür. \%50'den azında ise iskemik optik nöropati, santral retinal arter ya da ven tıkanıklığına bağlı görmede azalma, dilate pupil, korneal duyu azalması ve meningismus belirtileri ve çok ender olarak venöz infarkta bağlı hemiparezi ve nöbetler görülebilir ${ }^{31}$.

Septik kavernöz sinüs trombozunda laboratuvar bulgularına bakıldığında lökositoz \%70 oranında vardır. Yüksek çözünürlüklü, kontrast tutulumlu bilgisayarlı tomografi ile kavernöz sinüsteki genişleme ve düzensiz dolum defektleri görülür. Dilate superior oftalmik venlere ilaveten, yumuşak doku ödemi ve proptozis de görülebilir ${ }^{32}$.

Septik kavernöz sinüs trombozunun tedavisi bir enfeksiyon hastalıkları uzmanı konsültasyonu eşliğinde değerlendirilmeli ve üçüncü kuşak sefalosporin, nafsilin ve metronidazol içermelidir. Düşük molekül ağırIıklı heparin ile antikoagülan tedavinin mortalite ve morbiditeyi azalttığı gösterilmiştir ${ }^{31-33}$. Steroid tedavisinin uygulanması konusu tartışmalıdır. Parenkimi içeren septik kavernöz sinüs trombozu durumlarında kullanılmalıdır ${ }^{34}$. Aseptik kavernöz sinüs trombozunda altta yatan hastalığa ve koagülasyon durumu dikkate alınarak uygulanmalıdır. Klinik olarak septik ve aseptik kavernöz sinüs trombozunu ayırt etmek zor olduğu için, septik etiyoloji dışlanana kadar antibiyotik tedavisinin başlanması önerilmektedir.

\section{Anevrizmal Üçüncü Sinir Paralizisi}

Okulomotor sinir paralizilerinin \%9-36 intrakranial anevrizmadan kaynaklıdır ${ }^{35}$. Anevrizmaların yaklaşık \%40’ posterior komünikan arter, oftalmik arter ve kavernöz sinüs seviyesinde lokalizedir. Posterior komünikan arter anevrizmaları \%30-60 oranında üçüncü sinir paralizisine eşlik eder ${ }^{36}$. Anevrizma rüptürü yaşın ilerlemesi, sigara içilmesi, kadın cinsiyet, hipertansiyon, pozitif aile öyküsü, anevrizmanın boyutunun 10 mm'den büyük olması, polikistik böbrek 
hastalığı gibi genetik durumlar, posterior komünikan arter ve basiler yerleşimli anevrizmalarda daha sıktır ${ }^{37,38}$. Anevrizmal 3. sinir paralizisi tipik olarak ağrı ile beraber zayıf ışık reaksiyonu olan mid-dilate pupil ve pitozis eşliğinde yukarı bakış, aşağı bakış ve içe bakışta kısıtlılıkla karakterize tam ya da kısmi bir paralizidir (Figür 4). Basıya bağlı üçüncü sinir paralizisini iskemiye bağlı olan tipten ayırmak için pupilla tutulumu önem arz etmektedir ${ }^{39}$. Basıya bağlı olanda santral somatomotor lifler ve periferal superomedial lifler etkilenir. Dolayısıyla iskemiye bağlı paralizilerde pupil tutulumu olmayacaktır ${ }^{39,40}$.

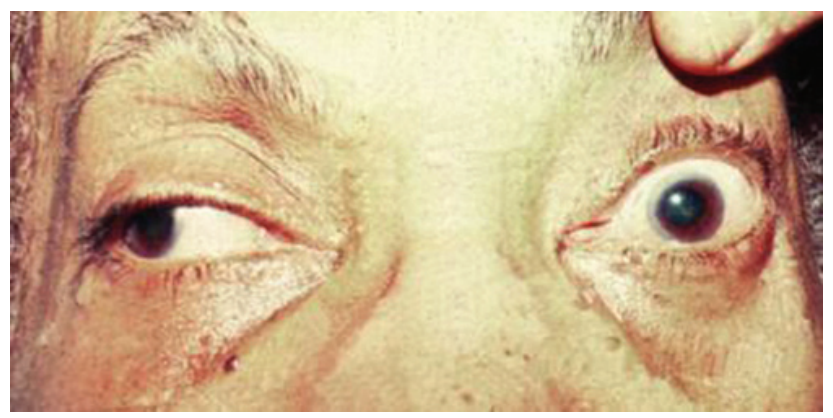

Figür 4. Anevrizmal 3. sinir paralizisi.

Dijital substraksiyon anjiyografisi serebral anevrizma tanısında altın standart tekniktir ancak \%1-2 oranında nörolojik morbidite riski taşır. Manyetik rezonans görüntüleme ve bilgisayarlı tomografi anjiyografi gibi tetkikler özellikle 5 mm'den küçük anevrizmalarda dijital substraksiyon anjiyografisinin yerini alamasa da \%95 oranında anevrizmaları belirleyebilir. Anevrizmal üçüncü sinir paralizisinde kısmi ya da tam paralizinin iyileşmesi pitozisin düzelmesiyle başlar ve pupilla ve ekstraoküler kasların tutulumu kalıcı olabileceği gibi aberran rejenerasyonla iyileşebilir ${ }^{41}$.

\section{Anizokori}

Anizokorinin değerlendirilmesi genellikle başlangıç tarihini belirlemek açısından zordur. Görünüşte akut anizokori yeni olmuş gibi görünse de aslında daha önceden olmuş fakat göz ağrısı ya da baş ağrısı gibi başka bir semptom değerlendirilirken muayene sırasında keşfedilmiş olabilir. Anizokori, ışıkta zayıf ışık reaksiyonu ve büyük anizokori oluşturanlar ve karanlıkta karanlık dilatasyonu olmadan büyük anizokori oluşturanlar olmak üzere sınıflandırılabilir ${ }^{42}$. Dilatasyonda gecikme, ışık kapatıldıktan sonra pupillanın özellikle ilk 5 saniye sırasında gelişen yavaş dilatasyonunu tarif eder ve bu bulgu özellikle Horner sendromunda önemli bir bulgudur. Sempatik parezi olarak da adlandırılan Horner sendromu farmakolojik olarak kokain ve aproklonidin testleri ile kontrol edilebilir. Kokain sonrası anizokori $8 \mathrm{~mm}$ üzerinde iken, aproklonidin sonrası eski hale dönüş gözlenir ${ }^{1,42}$.

\section{Karotis Arter Diseksiyonu}

Karotis arter diseksiyonu intimal duvarın yıkımıyla intramural hematom oluşmasına neden olan bir durumdur. 100.000 kişide 3 oranında, beşinci dekatta ve erkeklerde nispeten biraz fazla görülmektedir. Genç erişkinlerde inmenin yaklaşık \%20'sinin nedeni karotis arter diseksiyonudur ${ }^{43}$. Diseksiyon travmatik ya da spontan olabileceği gibi bazen de altta yatan fibromusküler displazi ya da bir konnektif doku hastalığı olabilir ${ }^{44}$. Aynı tarafta olan baş ağrısı karotis arter diseksiyonunda \%70 oranla en sık görülen belirti olmakla beraber, vakaların yarısında başlangıç bulgusudur. Aynı tarafta olan boyun, göz ve kulak ağrısı daha ender görülür (\%10-30 ${ }^{45}$. Ani ağrılı Horner sendromu özellikle genç hastalarda servikal diseksiyonu akla getirmelidir. Diseksiyonun daha ender oftalmolojik bulguları ise geçici monoküler görme kaybı, arteritik olmayan anterior iskemik optik nöropati, posterior iskemik optik nöropati, santral retinal ven tıkanıklı̆ıı, oküler iskemik sendrom ve okuler motor nöron paralizileridir ${ }^{46}$.

Dijital subtraksiyon anjiyografisi düşük özgüllükte olması ve inme riski nedeniyle yerini invazif olmayan görüntüleme tekniklerinden bilgisayarlı tomografi anjiografi ve manyetik rezonans anjiyografi gibi tetkiklere bırakmıştır (Figür 5). Bu tetkikler damar lümenini, arter duvarını ve intramural hematomu \%85 duyarlılık ve \%95 özgüllükle net bir şekilde gösterir $^{47,48}$. Karotis diseksiyonunun tedavisi randomize çalışmaların olmaması nedeniyle tartışma- 
lıdır ${ }^{49}$. Antiplatelet ve antikoagülan tedaviler diseksiyonun durumu monitorize edilerek 3-6 ay süreyle önerilmektedir. Karotis arter diseksiyonundaki iskemik inmenin nedeni emboli olsa da yapılan bir çalışmada, antiplatelet ve antikoagülan tedavinin herhangi bir üstünlüğünün olmadığı öngörülmüştür ${ }^{50}$. Trombolitik ve endovasküler tedavi daha ileri çalışmalar gerektirmektedir. Klinik sonuçlar vakaların \%90'ında iyi olsa da bazı vakalarda tam iyileşme sağlanamamaktadır ${ }^{51}$.

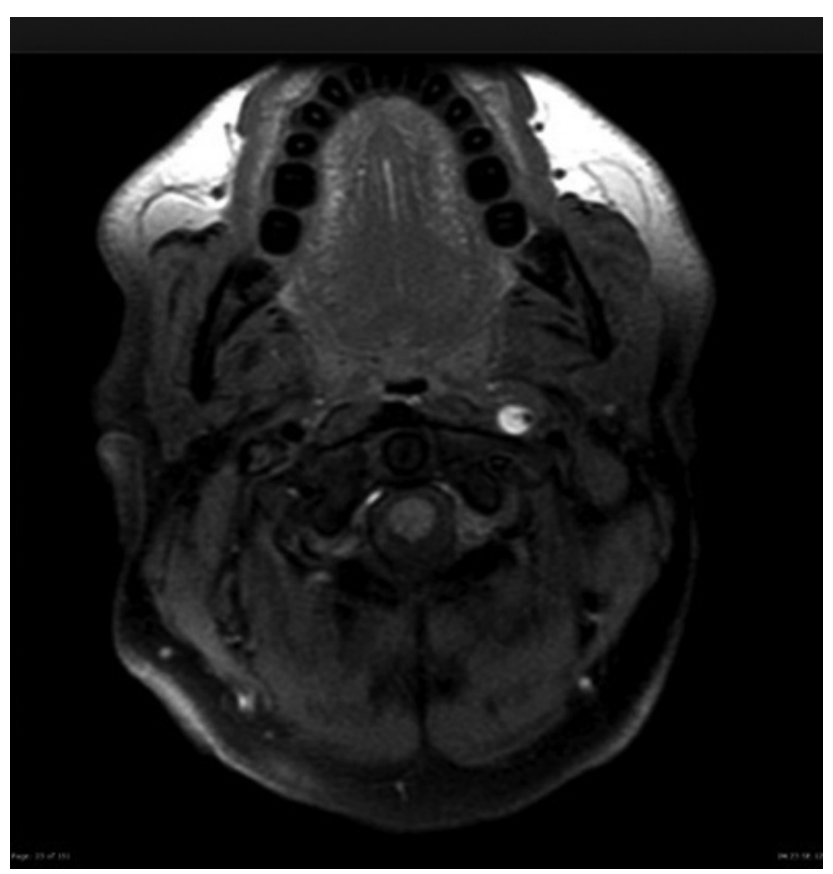

Figür 5. Karotis arter diseksiyonu.

\section{SONUÇ}

Nöro-oftalmolojik acil bir duruma yaklaşımda en önemli basamak beraberinde gelişen görme kaybı, diplopi, baş ağrısı gibi bulguların da sorgulandığı ayrıntılı bir öykü alınmasıdır. Klinisyenler anterior iskemik optik nöropati, mukormukozis, kavernöz sinüs trombozu, basıya bağlı üçüncü sinir paralizileri ve karotis diseksiyonu ilişkili Horner sendromu gibi nörooftalmolojik aciller açısından tetikte olmalıdır. Arteriyel anterior iskemik optik nöropati kalıcı ve ciddi görme kaybı, inme veya aort disseksionu ile birliktelik gösterebilen ve acil kortikosteroid tedavisi gereksinimi duyulan ciddi bir durumdur.
Erken tedavi uygulanmasına rağmen, çoğu zaman yüksek morbidite oranları ile seyreden bu klinik durumlara vakit kaybetmeden yaklaşım nispeten daha iyi sonuçlar alınması açısından son derece önem taşımaktadır.

\section{KAYNAKLAR}

1. Miller N, Newman N, Biousse V, Kerrison J. Walsh \& Hoyt's Clinical Neuro-Ophthalmology. 6th edition. Philadelphia, Lippincott Williams \& Wilkins; 2004: 83-150.

2. Trobe J. The Neurology of Vision. Contemporary Neurology Series. Oxford, United Kingdom: Oxford University Press; 2001: 97-145.

3. Yaman A, Söylev M. İskemik Optik Nöropati. Turkiye Klinikleri J Ophthalmol 2009;2(3):74-82.

4. Johnson LN, Arnold AC. Incidence of nonarteritic and arteritic anterior ischemic optic neuropathy. Population-based study in the state of Missouri and Los Angeles County, California. J Neuroophthalmol 1994;14:38-44. http://dx.doi.org/10.1097/00041327-199403000-00011

5. Hayreh SS, Podhajsky PA, Zimmerman B. Ocular manifestations of giant cell arteritis. Am J Ophthalmol 1998;125:50920.

http://dx.doi.org/10.1016/S0002-9394(99)80192-5

6. Liozon E, Herrmann F, Ly K, et al. Risk factors for visual loss in giant cell (temporal) arteritis: a prospective study of 174 patients. Am J Med 2001;111:211-7.

http://dx.doi.org/10.1016/S0002-9343(01)00770-7

7. Siatkowski RM, Gass JD, Glaser JS, et al. Fluorescein angiography in the diagnosis of giant cell arteritis. Am J Ophthalmol 1993;115:57-63.

http://dx.doi.org/10.1016/S0002-9394(14)73525-1

8. Parikh M, Miller NR, Lee AG, et al. Prevalence of a normal C-reactive protein with an elevated erythrocyte sedimentation rate in biopsy-proven giant cell arteritis. Ophthalmology 2006;113:1842-5.

http://dx.doi.org/10.1016/j.ophtha.2006.05.020

9. Foroozan R, Danesh-Meyer H, Savino PJ, et al. Thrombocytosis in patients with biopsy-proven giant cell arteritis. Ophthalmology 2002;109:1267-71. http://dx.doi.org/10.1016/S0161-6420(02)01076-X

10. Danesh-Meyer HV, Savino PJ, Eagle RC, et al. Low diagnostic yield with second biopsies in suspected giant cell arteritis. J Neuroophthalmol 2000;20:213-5. http://dx.doi.org/10.1097/00041327-200020030-00011

11. Ball EL, Walsh SR, Tang TY, Gohil R, Clarke JM. Role of ultrasonography in the diagnosis of temporal arteritis. Br J Surg 2010;97:1765-71.

http://dx.doi.org/10.1002/bjs.7252

12. Font $C$, Cid MC, Coll-Vinent B, et al. Clinical features in patients with permanent visual loss due to biopsy-proven giant cell arteritis. Br J Rheumatol 1997;36:251-4. http://dx.doi.org/10.1093/rheumatology/36.2.251

13. Hayreh SS, Biousse V. Treatment of acute visual loss in giant cell arteritis: should we prescribe high-dose intravenous steroids or just oral steroids? J Neuroophthalmol 2012;32:278-7.

http://dx.doi.org/10.1097/WNO.0b013e3182688218

14. Hoffman GS, Cid MC, Hellmann DB, et al. A multicenter, ran- 
domized, double-blind, placebo-controlled trial of adjuvant methotrexate treatment for giant cell arteritis. Arthritis Rheum 2002;46:1309-18. http://dx.doi.org/10.1002/art.10262

15. Hoffman GS, Cid MC, Rendt-Zagar KE, et al. Infliximab for maintenance of glucocorticosteroid-induced remission of giant cell arteritis: a randomized trial. Ann Intern Med 2007;146:621-30. http://dx.doi.org/10.7326/0003-4819-146-9-200705010-00004

16. Nesher G, Berkun $Y$, Mates $M$, et al. Low-dose aspirin and prevention of cranial ischemic complications in giant cell arteritis. Arthritis Rheum 2004;50:1332-7. http://dx.doi.org/10.1002/art.20171

17. Semple PL, Webb MK, de Villiers JC, Laws ER. Pituitary apoplexy. Neurosurgery 2005;56:65-72. http://dx.doi.org/10.1227/01.NEU.0000144840.55247.38

18. Çevik B, Deniz FE, Aksoy D, Kurt S, Demir Ö , Barut H. İzole Okülomotor Sinir Paralizisi ile Prezente Olan Bir Pituiter Apopleksi Olgusu: Olgu Sunumu ve Literatür Derlemesi. Dicle Tıp Dergisi 2014;41(2):409-13. http://dx.doi.org/10.5798/diclemedj.0921.2014.02.0442

19. Nawar RN, AbdelMannan D, Selman WR, Arafah BM. Pituitary tumor apoplexy: a review. J Intensive Care Med 2008;23:75-90. http://dx.doi.org/10.1177/0885066607312992

20. Bills DC, Meyer FB, Laws ER, Jr, et al. A retrospective analysis of pituitary apoplexy. Neurosurgery 1993;33:602-8. http://dx.doi.org/10.1227/00006123-199310000-00007

21. Joshi N, Caputo GM, Weitekamp MR, Karchmer AW. Infections in patients with diabetes mellitus. $N$ Engl J Med 1999;341:1906-12. http://dx.doi.org/10.1056/NEJM199912163412507

22. Binder U, Maurer E, Lass-Florl C. Mucormycosis-from the pathogens to the disease. Clin Microbiol Infect 2014;20:60-6. http://dx.doi.org/10.1111/1469-0691.12566

23. Rees JR, Pinner RW, Hajjeh RA, et al. The epidemiological features of invasive mycotic infections in the San Francisco Bay Area, 1992-1993: results of Population-Based Laboratory Active Surveillance. Clin Infect Dis 1998;27:1138-47. http://dx.doi.org/10.1093/clinids/27.5.1138

24. Diwakar A, Dewan RK, Chowdhary A, et al. Zygomycosis-a case report and overview of the disease in India. Mycoses 2007;50:247-54. http://dx.doi.org/10.1111/j.1439-0507.2007.01382.x

25. Thurtell MJ, Chiu AL, Goold LA, et al. Neuro-ophthalmology of invasive fungal sinusitis: 14 consecutive patients and a review of the literature. Clin Experiment Ophthalmol 2013;41:56776.

http://dx.doi.org/10.1111/ceo.12055

26. Gamaletsou MN, Sipsas NV, Roilides E, Walsh TJ. Rhino-orbitalcerebral mucormycosis. Curr Infect Dis Rep 2012;14:423-34. http://dx.doi.org/10.1007/s11908-012-0272-6

27. Uğurlu ŞK, Sedat Selim S, Kopar A, Murat Songu M. Rinoorbital Mukormikozis: Dört Olgunun Klinik Bulgu ve Tedavi Sonuçları. Turk J Ophthalmol 2015;45:169-74.

28. Prabhu RM, Patel R. Mucormycosis and entomophthoramycosis: a review of the clinical manifestations, diagnosis and treatment. Clin Microbiol Infect 2004;10:31-47. http://dx.doi.org/10.1111/j.1470-9465.2004.00843.x

29. Rucker JC, Tomsak RL. Binocular diplopia. A practical approach. Neurologist 2005;11:98-110. http://dx.doi.org/10.1097/01.nrl.0000156318.80903.b1

30. Schuknecht B, Simmen D, Yuksel C, Valavanis A. Tributary venosinus occlusion and septic cavernous sinus thrombosis: CT and MR findings. Am J Neuroradiol 1998;19:617-26.
31. Kraus CL, Culican SM. Challenging presentations of cavernous sinus thrombophlebitis. J Ophthalmic Inflamm Infect 2012;2:133-6. http://dx.doi.org/10.1007/s12348-011-0053-7

32. Desa V, Green R. Cavernous sinus thrombosis: current therapy. J Oral Maxillofac Surg 2012;70:2085-91. http://dx.doi.org/10.1016/j.joms.2011.09.048

33. Coutinho JM, Ferro JM, Canhao P, et al. Unfractionated or low-molecular weight heparin for the treatment of cerebral venous thrombosis. Stroke 2010;41:2575-80. http://dx.doi.org/10.1161/STROKEAHA.110.588822

34. Canhao P, Cortesao A, Cabral M, et al. Are steroids useful to treat cerebral venous thrombosis? Stroke 2008;39:105-10. http://dx.doi.org/10.1161/STROKEAHA.107.484089

35. Keane JR. Third nerve palsy: analysis of 1400 personallyexamined inpatients. Can J Neurol Sci 2010;37:662-70. http://dx.doi.org/10.1017/S0317167100010866

36. Winn HR, Jane JA, Sr, Taylor J, et al. Prevalence of asymptomatic incidental aneurysms: review of 4568 arteriograms. J Neurosurg 2002;96:43-9. http://dx.doi.org/10.3171/jns.2002.96.1.0043

37. Menghini VV, Brown RD, Jr, Sicks JD, et al. Incidence and prevalence of intracranial aneurysms and hemorrhage in Olmsted County, Minnesota, 1965 to 1995. Neurology 1998;51:405-11. http://dx.doi.org/10.1212/WNL.51.2.405

38. Wiebers DO, Whisnant JP, Huston J, et al. Unruptured intracranial aneurysms: natural history, clinical outcome, and risks of surgical and endovascular treatment. Lancet 2003;362:10310. http://dx.doi.org/10.1016/S0140-6736(03)13860-3

39. Kissel JT, Burde RM, Klingele TG, Zeiger HE. Pupil-sparing oculomotor palsies with internal carotid-posterior communicating artery aneurysms. Ann Neurol 1983;13:149-54. http://dx.doi.org/10.1002/ana.410130207

40. Trobe JD. Third nerve palsy and the pupil. Footnotes to the rule. Arch Ophthalmol 1988;106:601-2. http://dx.doi.org/10.1001/archopht.1988.01060130655019

41. Gu DQ, Luo B, Zhang X, et al. Recovery of posterior communicating artery aneurysm-induced oculomotor nerve paresis after endovascular treatment. Clin Neurol Neurosurg 2012;114:1238-42. http://dx.doi.org/10.1016/j.clineuro.2012.03.016

42. Wilhelm H, Christopher K, Leigh RJ. Disorders of the pupil Neuro-Ophthalmology: Handbook of Clinical Neurology. Amsterdam, the Netherlands: Elsevier; 2011:427-66. http://dx.doi.org/10.1016/B978-0-444-52903-9.00022-4

43. Putaala J, Metso AJ, Metso TM, et al. Analysis of 1008 consecutive patients aged 15 to 49 with first-ever ischemic stroke: the Helsinki young stroke registry. Stroke 2009;40:1195-203. http://dx.doi.org/10.1161/STROKEAHA.108.529883

44. Dziewas R, Konrad C, Drager B, et al. Cervical artery dissectionclinical features, risk factors, therapy and outcome in $126 \mathrm{pa}-$ tients. J Neurol 2003;250:1179-84. http://dx.doi.org/10.1007/s00415-003-0174-5

45. Silbert PL, Mokri B, Schievink WI. Headache and neck pain in spontaneous internal carotid and vertebral artery dissections. Neurology 1995;45:1517-22. http://dx.doi.org/10.1212/WNL.45.8.1517

46. Biousse V, Touboul PJ, D'Anglejan-Chatillon J, et al. Ophthalmologic manifestations of internal carotid artery dissection. Am J Ophthalmol 1998;126:565-77. http://dx.doi.org/10.1016/S0002-9394(98)00136-6

47. Mehigan JT, Olcott CT. The carotid "string" sign. Differential 
diagnosis and management. Am J Surg 1980;140:137-43. http://dx.doi.org/10.1016/0002-9610(80)90430-4

48. Levy C, Laissy JP, Raveau V, et al. Carotid and vertebral artery dissections: three-dimensional time-of-flight MR angiography and MR imaging versus conventional angiography. Radiology 1994;190:97-103.

http://dx.doi.org/10.1148/radiology.190.1.8259436

49. Menon R, Kerry S, Norris JW, Markus HS. Treatment of cervical artery dissection: a systematic review and meta-analysis. J Neurol Neurosurg Psychiatry 2008;79:1122-7. http://dx.doi.org/10.1136/jnnp.2007.138800

50. Benninger DH, Georgiadis D, Kremer $C$, et al. Mechanism of ischemic infarct in spontaneous carotid dissection. Stroke 2004;35:482-5.

http://dx.doi.org/10.1161/01.STR.0000109766.27393.52

51. Lee VH, Brown RD, Mandrekar JN, Mokri B. Incidence and outcome of cervical artery dissection: a population-based study. Neurology 2006;67:1809-12.

http://dx.doi.org/10.1212/01.wnl.0000244486.30455.71 